\title{
AMINO ACIDS AS CONTROLLING FACTOR FOR THE MINERALOGY AND THE CHEMISTRY OF SOME BIVALVE AND GASTROPOD SHELLS
}

\author{
Mohamed A. Shata and Wagdy M.El-Sarraf \\ National Institute of Oceanography and Fisheries, Alexandria, Egypt
}

Key words: Amino acids, chemistry, mineralogy, bivalves, gastropods, shells calcification.

\section{ABSTRACT}

The present study entails with the role of amino acids in the 1 mineralogical and chemical composition of some bivalve and gastropod shells. The common skeletal minerals reported for the studied shells were found to be aragonite, calcite, and $\mathrm{Mg}$-calcite. The bivalve Tridacna elongata showed high level of calcite and low level of aspartic the acid. Aragonite recorded high levels in the other examined species.

- Glycine, isoleucine and proline represented the extreme higher values among the neutral amino acids in all examined shells. The neutral amino acids can be quantitatively arranged in the following order; Glycine $>$ Isoleucine $>$ Proline $>$ Alanine $>$ Leucine $>$ Valine $>$ Serine $>$ Threonine.

The chemical study of the investigated shells indicates that, copper recorded its maximum value $\left(33 \mu \mathrm{gg}^{-1}\right)$ in the bivalve Tridacna elongata and its minimum $\left(12 \mathrm{\mu gg}^{-1}\right)$ in the gastropod Conus coronatus. The maximum values of zinc, lead, iron and manganese were recorded in bivalve Acanthocardium aculeata whereas, the studied gastropods revealed lower values for these elements. This trend of the element distribution was observed also for calcisin and magnesium. Acidic amino acids seem to play an impo..ant role in fixation of calcium, nucleation of $\mathrm{CaCO}_{3}$ and growt? of the mineral phase. 


\section{INTRODUCTION}

The mineralogy and elemental composition of any carbonate is partly dependent upon the mode of precipitation. Most workers have supported an enzyme theory (the presence of various enzymes such as carbonic anhydrase or phosphorylase that determines the site of calcification). They suggested also the template theory (the nucleation and the form of the seed that related to the composition of the organic template or matrix upon which it forms). Some workers have favored crystal poison or electrochemical models (Milliman, 1974).

At present, many data favor the template theory of calcification, although not all organisms necessarily utilize this technique. Wilber et $a l$. (1969) supported the template model and pointed to this fact that, all carbonates, even ooids, contain a matrix of protein and amino acids (Mitterer, 1968). According to this model, shell nucleation involves the coordination of $\mathrm{Ca}$ ions to free carboxyl groups of acidic amino acids residues in the matrix protein (Hare and Abelson, 1965; Degens, 1967; Degens et al., 1967; Matheja and Degens, 1968; Jackson and Bischoff, 1971 and Degens, 1976). The spatial sequence of specific peptide chains and the nature of the organic matrix can determine the micro- architecture, (Hare and Abelson, 1965), as well as, the mineralogy of the precipitated shell. Matheja and Degens (1968) have explained this latter phenomenon by the influence of oxygen absorption by various proteinaceous compounds upon the coordination polyhedra; $\mathrm{Ca}^{+2} \mathrm{O}_{6}$ will form calcite and $\mathrm{Ca}^{+2} \mathrm{O}_{9}$ will favor aragonite. The differences in the ratios of protein compounds from one species to another also may have phylogenetic implications; (Hare and Abelson, 1965 and Ghiselin et al., 1967).

In many primitive phyla, calcification is extracellular softening point that the concentration of trace elements is controlled by the physicochemical processes (Kinsman, 1969). In contrast, advanced organisms, mollusks being the best example, calcify by passing cations through cellular tissues. This process can be effective in partitioning various elements.

The two elements most easily related to physicochemical processes are strontium and magnesium, although other elements such as iron also may be dependent upon the complexity of calcification. Lowenstam (1963 and 1964a,b) demonstrated that, more 
Amino acids as controlling factor for the mineralogy and the 149 chemistry of bivalve and gastropod shells

phylogenetically advanced organisms contain less strontium, the strontium being preferentially excluded by more complex calcification processes. Excluding mollusks from this picture, one can see a slight decrease in strontium with increasing physiologic complexity. Mollusks appear to be totally unique in their ability to selectively discriminate against strontium (Likins et al., 1963).

The specific role of amino acids in calcified proteinaeous organic matter depends on their negatively charged carboxylic group $\left(\mathrm{COO}^{-}\right)$which may act as concentration sites for calcium ions( Hare, 1963). Similarly, carbonate or bicarbonate could be concentrated on positively charged (basic) side chains (Muller and Suss, 1977).

The present investigation entails with the role of the amino acids in the mineralogical composition of the studied shells. The investigated species include two bivalve species, as well as three gastropod species.

\section{Hydrographic features of the study area:}

According to Anon (1997), the Bitter Lakes exhibited the denser water over the whole Suez Canal, Egypt (Fig.1). A salt barrier of salinity greater than $65 \%$ was established in the Bitter Lakes which acted as an obstacle for the migration of marine organisms between Mediterranean and Red Sea due to the existence of the salt bed at the lakes bottom. Soliman and Morcos (1990) suggested that the salt bed was about exhausted and its effect on salinity was insignificant. Therefore, the salinity in the lakes is expected to fluctuate within the range $\pm 1.2 \%$ about the mean value of $42.3 \%$. Accordingly, the migration of the marine organisms between the joined seas can occur at any time without any osmotic problem.

\section{Analytical methods:}

Representative specimens from each examined species have been collected from the area of study (Bitter Lakes of Suez Canal). For both heavy elements and mineralogical analyses, the shells were pulverized to pass through 44- $\mu$ mesh sieve-screen, after which the powder has been subjected to ultra-sonic to ensure its cleaning. The powdered samples were divided into two portions; the 
first one was subjected to X-Ray diffraction analysis, using diffractometer model Philips (1840) to determine the mineralogical composition of the different species.

The conditions under which the measurements were taken were as follows; Wave length $\mathrm{Cu} \mathrm{K} \alpha=1.54050$.

Anode/strain/cathode/current $=45 \mathrm{~K}$.v. $/ 25 \mathrm{~m}$.A.Filter-Nickel

Senstivity $=4 \times 100$ and $10^{3}$ counts/second.

Measurements range $\left(2 \theta^{\circ}\right)=20-60^{\circ}$

The second portion was prepared for determination of amino acids according to the procedure modified by El-Sarraf et. at. (1984) using amino acid analyzer Beckman model $119 \mathrm{CL}$. Tubes containing about $50 \mathrm{mg}$ dried, homogenous powder of the examined shells with $5 \mathrm{ml}$ of $6 \mathrm{~N} \mathrm{Hcl}$ were sealed under vacuum and hydrolyzed for 22-24 hours at $110^{\circ} \mathrm{C}$.

\section{RESULTS AND DISCUSSION}

\section{Amino acids analysis:}

Analytical data of amino acids in the studied shell of both bivalves and gastropods are given in Table 1 and Figures $2 \& 3$. The total amino acids content in the investigated shells varies from 888.93 $\mu \mathrm{gg}^{-1}$ in Conus coronatus to $4397.11 \mu \mathrm{g} \cdot \mathrm{g}^{-1}$ in Fusinus marmoratus. The high levels of amino acids are believed to be due to the high concentration of organic matter in the matrix of the studied shells.

The ratio of basic amino acids to the total amino acids in the studied bivalve shells ranged from $6.9 \%$ to $9.14 \%$, whereas in the gastropods varied from 7.8 to $11.4 \%$. In the fact, the ratio of basic amino acids to the total amino acids in the recent skeletal carbonate approximates to $10 \%$ (Terashema and Tanaka, 1976).

Concerning acidic amino acids, they recorded higher concentrations in comparison with the basic in the bivalves. They ranged from 27 to $28.9 \%$ relative to the total amino acids. The gastropods recorded values that varied from 21 to $33.1 \%$. Aspartic acid was the most abundant amino acid, ranging from 11 to $21.5 \%$ relative to total amino acids. Terashema and Tanaka (1976), King (1977) indicated that aspartic acids are the most abundantin the calcareous microfossils. 
Amino acids as controlling factor for the mineralogy and the 151 chemistry of bivalve and gastropod shells

The neutral amino acids fluctuate from $47.5 \%$ in Acanthocardium aculeatum to $54.8 \%$ in Tridacna elongata. In gastropods, it recorded 51.2, 52.3 and $53.3 \%$ in Cerithitum caeruleum, Conus coronatus and Fusinus marmoratus respectively.

Glycine, isoleucine and proline represent the extreme higher values among the neutral amino acids in all examined shells. The higher values of glycine could be owed to the decomposition of serine and threonine. The neutral amino acids can be quantitatively arranged in the following order;

Giycine $>$ Isoleucine $>$ Proline $>$ Alanine $>$ Leucine $>$ Valine $>$ Serine $>$ Threonine.

Sulfur amino acids, cystine revealed higher values, but methionine recorded lower values.

The difference in the concentrations of the amino acids components may be interpreted on the basis of the decomposition pathways of serine and threonine via dehydration (Bada and Man, 1980; Bada et al. 1982). Aromatic amino acids (tyrosine and phenylanaline) revealed relatively moderate concentrations ranging between 2.2 and $4.95 \%$ relative to the total amino acids.

Ammonia varied between $54.4 \mu \mathrm{g} \mathrm{g}^{-1}$ in Fusinus marmoratus and $417.7 \mu \mathrm{g} \mathrm{g}^{-1}$ in Cerithium caeruleum. Ammonia concentrations in bivalves are lower than that of gastropods.

The relatively higher values of both acidic and basic amino acids components in gastropods compared with those of bivalves may be due to phylogenic implication, as well as, to differential skeletal composition.

\section{Chemistry of the investigated shells:}

Both quality and quantity of the elements required for building up the shell during the life span of an organism depend on the selective uptake of the organism, as well as, on the surrounding ecological conditions. Degens (1976) mentioned the ability of aspartic acid, serine and glycine to coordinate metal ions. 
Copper recorded its maximum value $\left(33 \mu \mathrm{g} \mathrm{g}^{-1}\right)$ in the bivalve Tridacna elongata and its minimum $\left(12 \mu \mathrm{g} \mathrm{g}^{-1}\right)$ in the gastropod Conus coronatus. The maxima values of zinc, lead, iron and manganese were recorded in bivalve Acanthocardium. aculeata (Table 2), whereas the studied gastropods reveal lower values for these elements. This trend of the element distribution was observed also for calcium and magnesium. Acidic amino acids seem to play an important role in fixation of calcium, nucleation of $\mathrm{CaCO}_{3}$ and growth of the mineral phase.

The organic matrix recorded its maximum concentration $(7.88 \%)$ in the gastropod Cerithium caerculeum and the minimum $(2.29 \%)$ in Conus coronatus.

\section{Mineralogical composition:}

The common skeletal minerals that reported for the studied shells found to be aragonite, calcite and $\mathrm{Mg}$-calcite (Table 3 and Figs. $4 \mathrm{a}$,b). Aragonite ranged between $29.71 \%$ in the bivalve Tridacna elongata and $95.78 \%$ in the gastropod Conus coronatus (Table 3$)$. Vise versa, calcite reveals its minimum value $(2.11 \%)$ in the gastropod Conus coronatus and its maximum (70.29\%) in the bivalve Tridacna elongata. However, high levels of calcite and low level of aspartic acid were shown in the bivalve Tridacna elongata. This could not be related to the high levels of both neutral and basic amino acid. Aragonite recorded high levels in the other examined species. This can be interpreted on that, glutamic and aspartic acids inhibited the transformation of aragonite into calcite. Degens (1976) mentioned that, the acidic amino acids form a protective overgrowth on aragonite surface.

The correlation patterns of the individual amino acids are demonstrated by various connections with a type of skeletal matrices. Threonine, serine, glycine and alanine concentrations can be interpreted on the basis of the decomposition pathways of serine and threonine. The decomposition reactions of both serine and threonine could be useful as geochronological indicator (Bada and Man, 1980).

The relations between glycine and aspartic acid also threonine with glycine and proline with glycine, aspartic against threonine and glutamic acid with proline reveal linear relationships (Figs.5a-f). This 
may suggest that one of the amino acid fractions in the shell matrices be related to the type of protein.

The negative correlation between the measured copper in the investigated species and aragonite $(r=-0.98)$ from one hand and the positive with calcite $(r=0.90)$ from the other hand reveals the incorporation of copper into the crystal lattice of calcite. The correlation matrix shows no effective interrelation between copper and the determined amino acid fractions. Lead shows positive correlation with $z$ inc and manganese (Figs. $6 \mathrm{a}$ and $\mathrm{b}$ ), whereas all are adsorbed on the calcite surface. The negative correlation between lead and Cystine (Fig. 7a) reveals that, cystine may follow various metabolic pathways; -SH- group is oxidized and then removed as sulfate or lead sulfate. The positive correlation between manganese and tyrosine (Fig. $7 \mathrm{~b}$ ) iliustrates that; $\mathrm{Mn}^{+2}$ is an essential micronutrient for many enzymes that activated by manganese (Fostner \&Wittmann, 1981). Magnesium is positively correlated with $\mathrm{Mg}$-calcite $(r=0.95)$. The positive correlation of magnesium with both aspartic acid and proline $(r=0.87)$ could be interpreted on the basis that, the catabolism of amino acids required enzyme cofactors such as magnesium during irreversible reactions. The negative correlation between calcium and tyrosine( $r=$ 0.94) may be related to that, magnesium inhibited the calcification processes in the living organisms, also tyrosine may reduce the calcium precipitation in the skeletal matrix. The positive correlations between aspartic acid with Proline and tyrosine acid with the organic carbon $(r=0.87,0.92,0.94)$ indicate that, the organic carbon contains protein fractions in the shell matrix Magnesium is positively correlated with organic carbon reflecting its adsorption onto the organic matrix. The negative correlation between calcite and cystine $(r=0.91)$ may be related to that, cystine inhibits the calcite formation. The positive correlation between $\mathrm{Mg}$-calcite and tyrosine $(r=0.93)$ may be attributed to their association in the same phase during the skeletal calcification of organisms.

\section{Conclusion}

The common skeletal minerals reported for the studied shells were found to be aragonite, calcite, and $\mathrm{Mg}$-calcite. Tridacna elongata showed high levels of calcite and low level of aspartic acid. This could not be related to the high levels of both neutral and basic amino acid. Aragonite recorded high levels in the other examined species. 
This can be interpreted on that, glutamic and aspartic acids inhibit the transformation of aragonite into calcite.

The relatively higher values of both acidic and basic amino acids components in gastropods in comparison with those of bivalves may be due to phylogenic implication, as well as, to differential skeletal composition. Glycine, isoleucine and proline represent the extreme higher values among the neutral amino acids in all examined shells. The higher values of glycine could be owed to the decomposition of serine and threonine. The neutral amino acids can be quantitatively arranged in the following order;

Glycine $>$ Isoleucine $>$ Proline $>$ Alanine $>$ Leucine $>$ Valine $>$ Serine $>$ Threonine.

The chemical study of the investigated shells indicates that, copper recorded its maximum value $\left(33 \mu \mathrm{gg}^{-1}\right)$ in the bivalve Tridacna elongata and its minimum (12 $\left.\mu \mathrm{gg}^{-1}\right)$ in the gastropod Conus coronatus. The maxima values of zinc, lead, iron and manganese were recorded in bivalve Acanthocardium aculeata whereas the studied gastropods reveal lower values for these elements. This trend of the element distribution was observed also for calcium and magnesium. Acidic amino acids seem to play an important role in fixation of calcium, nucleation of $\mathrm{CaCO}_{3}$ and growth of the mineral phase.

\section{ACKNOWLEDGMENT}

The authors wish to express their gratitude to Dr. A. K. Hassan for providing the samples used in this work. 
Amino acids as controlling factor for the mineralogy and the 155 chemistry of bivalve and gastropod shells

\section{REFERENCES}

Anon., (1997). Vulnerability assessment of the low-lying coastal areas in the southern part of the Suez Canal, in the context of climate change and sea level "Egypt". Suez Canal University and UNEP Report, 205 pp.

Bada, J. L. and Man, E.H. (1980). Amino acids diagensis in Deep Sea Drilling Project cores: Kinetic and Mechanisms of some reactions and their applications in geochronology and in paleotempertature and heat flow determinations. Earth Sci. Rev., 16:21-55.

Bada, J. L., Hoopes, E. and Ho, M.S. 1982). Combined amino acids in Pacific Ocean waters. Earth and planetary Science letters, 58: 276-284.

Degens. E.T., Spencer, D.W. \& Parker, R.H. (1967). Paleochemistry of molluscan shell protein. Comp. Biochem. Physiol., 20: 553-579.

Degens. E.T. (1967). Diagensis of organic matter, In:" Diagensis in sediments". G. Larsen and G.V. Chilinger (eds.), Elsevier, Amasterdam-London-New York, 343-390.

Degens. E.T. (1976). Molecular mechanisms in carbonate, phosphate and silica deposits in the living cell. Topics Current Chem., 64: 1-112.

El-Sarraf, W.M.; Olah, J. and Toh, E.O (1984). Seston and sediment amino acid in Lake Balton. Aquacultura Hungarica (Szarvas), 4: 97-102.

Fostner, U., and Wittmann, G. T.E: (1981). Metal pollution in the aquatic environment. Springer Verlag Berlin, $486 \mathrm{pp}$. 
Ghiselin, M .T; Degens, E.T; Spencer, D.W. and Parker, R.H. (1967). A phylogenetic survey of molluscan shell matrix protein. Berviora No. 262, p35.

Hare, P. E. (1963). Amino acids in the proteins from aragonite and calcite in the shells of Mytilus californians. Sci., 139:216-217.

Hare, P. E. and Abelson, P. H. (1965). Amino acid composition of some calcified protein. Carnegie. Inst. Wash. Ycarbook 64:223-232.

Jackson, T. A. and Bischoff, J.L. (1971). The influence of amino acids on the kinetic of the recrystallization of aragonite to calcite. J. Geol., 79: 493-497.

King, K. Jr. (1977). Amino acid survey of recent calcareous and siliceous deep- sea microfossils. Micropaleontology, 23 (2): 180-193.

Kinsman, D.J.J. (1969). Interpretation of $\mathrm{Sr}^{+2}$ concentrations in carbonate minerals and rock. J. Sediment. Petrol., 39: 486-508.

Likins, R. C., Bergy, E.G. and Posner, A.S., (1963). Comparative fixation of calcium and strontium by snail shell. Ann. N. Y. Acad. Sci., 109: 269-277.

Lowenstam, H.A. (1963). Biological problems relating to the composition and diagensis of sediments. In: "The Earth Sciences" T.W. Donnelly (ed.), 137-195. pp. Chicago: The Univ. Chicago Press.

Lowenstam, H.A. (1964a). Sr / Ca ratio of skeletal aragonites In: "Isotopic and Cosmic Chemistry". Amsterdam: North Holland Publ. Co., 114 -132. pp.

Lowenstam, H.A. (1964b). Coexisting calcites and aragonites from skeletal carbonates of marine organisms and their strontium and magnesium contents In: "Recent Researches in the fields of Hydrosphere and Nuclear Geochemistry". Tokyo: Maruzen Co., Ltd. pp.373-404.

Matheja, J. and Degens, E. T. (1968). Molkulare Entwicklung mineralisationfahiger organisher Matrizen. Neues Jahrb. Geol. Paleanto. Mh., No. 4 : 215-229. 
Amino acids as controlling factor for the mineralogy and the 157 chemistry of bivalve and gastropod shells

Milliman,J.D.(1974).Skeletal components.n:"Marine Carbonates". part 1, Berlin, Heidelberg, New York, 375 p.

Mitterer, R.M. 1968). Amino acid composition of organic matrix in calcareous oolites. Sci., 162: 1498-1499.

Muller, P. J. and Suess, E. (1977). Interaction of organic compounds with calcium carbonate-III. Amino acid composition of sorbed layers. Geochimica et cosmochemica Acta,41

Soliman, G.F. and Morcos, S.A. (1990). The Bitter Lakes between the past and the present. Regional Symp. Environ. Stud. (UNARC), Alexandria, 334-356.

Terashema, M. and Tanaka, M. (1976). Amino acids in Cenozoic limestone from Japan. Bull. Geol. Surv. Japan., 27: 613-624.

Wilber, K.M., Colinvaux I. H. and Watabe, N. (1969): Electron microscope study of calcification in the algae Halimeda (order Siphonals). Physiologia 8:27-35. 
Talole (1): Amino arids constiruents in the skeletal material of the studied biyalve and gascroprods species ( $\mu \mathrm{g}-\mathrm{g}^{-1} \mathrm{dry}$ weight).

\begin{tabular}{|c|c|c|c|c|c|}
\hline & \multicolumn{2}{|c|}{ Bivalves } & \multicolumn{3}{|c|}{ Gastropods } \\
\hline A rainu acids & 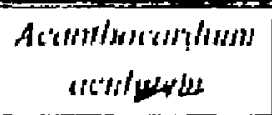 & 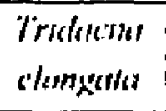 & $\begin{array}{l}\text { Cirithinm } \\
\text { cucrulcum }\end{array}$ & $\begin{array}{c}\text { C'smms } \\
\text { coronalus }\end{array}$ & $\begin{array}{c}\text { Fisimins } \\
\text { marmorahns }\end{array}$ \\
\hline $\begin{array}{l}\text { 1)Bassic } \\
\text { amimo arids }\end{array}$ & & - & & . & \\
\hline 1.ysine & 54.00 & 36.80 & 85.08 & 34.53 & 207.40 \\
\hline Ilisticline & 83.97 & 31.42 & 126.10 & 66.74 & 173.40 \\
\hline Aruinime & N.D. & N.D. & N.D. & N.D. & N.D. \\
\hline \multicolumn{6}{|l|}{$\begin{array}{l}21 \text { acidic } \\
\text { nonimen acids }\end{array}$} \\
\hline $\begin{array}{c}\text { Aspiutic } \\
\text { aridl }\end{array}$ & 227.88 & 111.22 & 579.20 & 97.61 & 700,00 \\
\hline $\begin{array}{c}\text { Cilut:amic } \\
\text { arciol }\end{array}$ & 208.9 .0 & 154.5 & 312.90 & 88.83 & 481.50 \\
\hline \multicolumn{6}{|l|}{$\begin{array}{l}\text { 3) Noutral } \\
\text { jumino acids }\end{array}$} \\
\hline (ilycime & 153.80 & 91.95 & 251.60 & 101.55 & 352.10 \\
\hline Alatine & 85.54 & 57.90 & 185.00 & 60.83 & 248.30 \\
\hline Vuline & 97.94 & 57.45 & 131.20 & 38.27 & 231.80 \\
\hline Seriuc & $53.7 k$ & 61.30 & 169.00 & 46.10 & 223.72 \\
\hline Tluconine & 69.82 & 44.30 & 149.60 & 43,60 & 235.30 \\
\hline Pronliar & 119.70 & 83.10 & $\$ 91.90$ & 67.16 & 202.60 \\
\hline Isoleturine & 77.70 & 79.22 & 150.10 & 60.04 & 626.60 \\
\hline Lencine & 58.60 & 64.28 & 149.70 & 49.74 & 425.50 \\
\hline \multicolumn{6}{|l|}{ t) Sinlliar } \\
\hline Cystilie & 53.46 & 39.60 & 66.82 & 68.20 & 81.90 \\
\hline Mlerhtonine & 15.65 & 17.69 & 17.38 & 12.17 & 17.38 \\
\hline \multicolumn{6}{|l|}{ 5)riromatic } \\
\hline Ty'rosine & 108.70 & 15.30 & 20.97 & 13.09 & 16.31 \\
\hline $\begin{array}{l}\text { Plicuylulumin } \\
\text {. }\end{array}$ & . $\quad+10.88$ & 37.30 & 106.85 & 40.47 & 173.30 \\
\hline $\begin{array}{l}\text { Total amina } \\
\text { aciul }\end{array}$ & 1510.118 & 983.88 & 2693.40 & 888.93 & 4397.11 \\
\hline Ammonin & 227.30 & 181.30 & 417.70 & 160.93 & 54.40 \\
\hline Tolet & 1737.38 & 1165.18 & 3111.10 & 1049.86 & 4451.51 \\
\hline
\end{tabular}


Amino acids as controlling factor for the mineralogy and the $\quad 159$ chemistry of bivalve and gastropod shells

Talle (2): Chenical constituents in the skeletal material of the studied bivatve and eastropad species ( $\mu \mathrm{g} \cdot \mathrm{g}^{-1}$ dry weight).

\begin{tabular}{|c|c|c|c|c|c|c|c|c|c|c|}
\hline Speries & Cu & Zn & Pb & Fe & Mn & $\mathbf{M g}_{\mathbf{g}}$ & $\mathrm{C} *$ & $\mathrm{CaCO}_{3} \%$ & $0 . c \%$ & T.O.M \%/6 \\
\hline \multicolumn{11}{|l|}{ I) Bivalves } \\
\hline $\begin{array}{l}\text { a) Acanth. } \\
\text { aculeata }\end{array}$ & 26.0 & 120 & 206 & 369 & 56 & 646 & 26.87 & 67.18 & 2.82 & 5.08 \\
\hline $\begin{array}{l}\text { b) Tridacna } \\
\text { elongata }\end{array}$ & 33 & 74 & 113 & 192 & 5.3 & $\$ 7.0$ & 26.89 & 67.22 & 1.79 & 3.21 \\
\hline \multicolumn{11}{|l|}{ II) gastropod } \\
\hline $\begin{array}{l}\text { a) Cerithium } \\
\text { cucriulcum }\end{array}$ & 18 & 25 & 76 & 204 & 8.05 & 956 & 20.56 & $51.4 \mathrm{t}$ & 4.38 & 7.98 \\
\hline $\begin{array}{l}\text { b) Conus } \\
\text { coronatus }\end{array}$ & 12 & 17 & 86 & 64 & 2.3 & 270 & 26.51 & 66.16 & 1.27 & 2.29 \\
\hline $\begin{array}{l}\text { c) Fusinus } \\
\text { marmoratus }\end{array}$ & 22 & 33 & 81 & 118 & 3.6 & 597 & 25.60 & 63.97 & 3.27 & 5.89 \\
\hline
\end{tabular}

Table (3): Mineralogical composition \% constituents in the skeletal material of 1 he studied bivalve and gaslropod spccies ( $\mu g \cdot g^{-1}$ dry weight).

\begin{tabular}{|c|c|c|c|}
\hline Species & Aragonite & Calcite \% & Mg-calcite \\
\hline $\begin{array}{l}\text { Acanth. } \\
\text { aruleata }\end{array}$ & 86.17 & 8.51 & 5,32 \\
\hline $\begin{array}{l}\text { Tridacna } \\
\text { elongata }\end{array}$ & 29.71 & 70.29 & - \\
\hline $\begin{array}{l}\text { Cerithium } \\
\text { culreculeum }\end{array}$ & 68 & 3.1 & 18.14 \\
\hline $\begin{array}{l}\text { Conus } \\
\text { coronatus }\end{array}$ & $\because 95.78$ & 2,31 & 2.11 \\
\hline $\begin{array}{l}\text { Fusinus } \\
\text { marmoratus }\end{array}$ & 70.1 & 5.1 & 5,9 \\
\hline
\end{tabular}




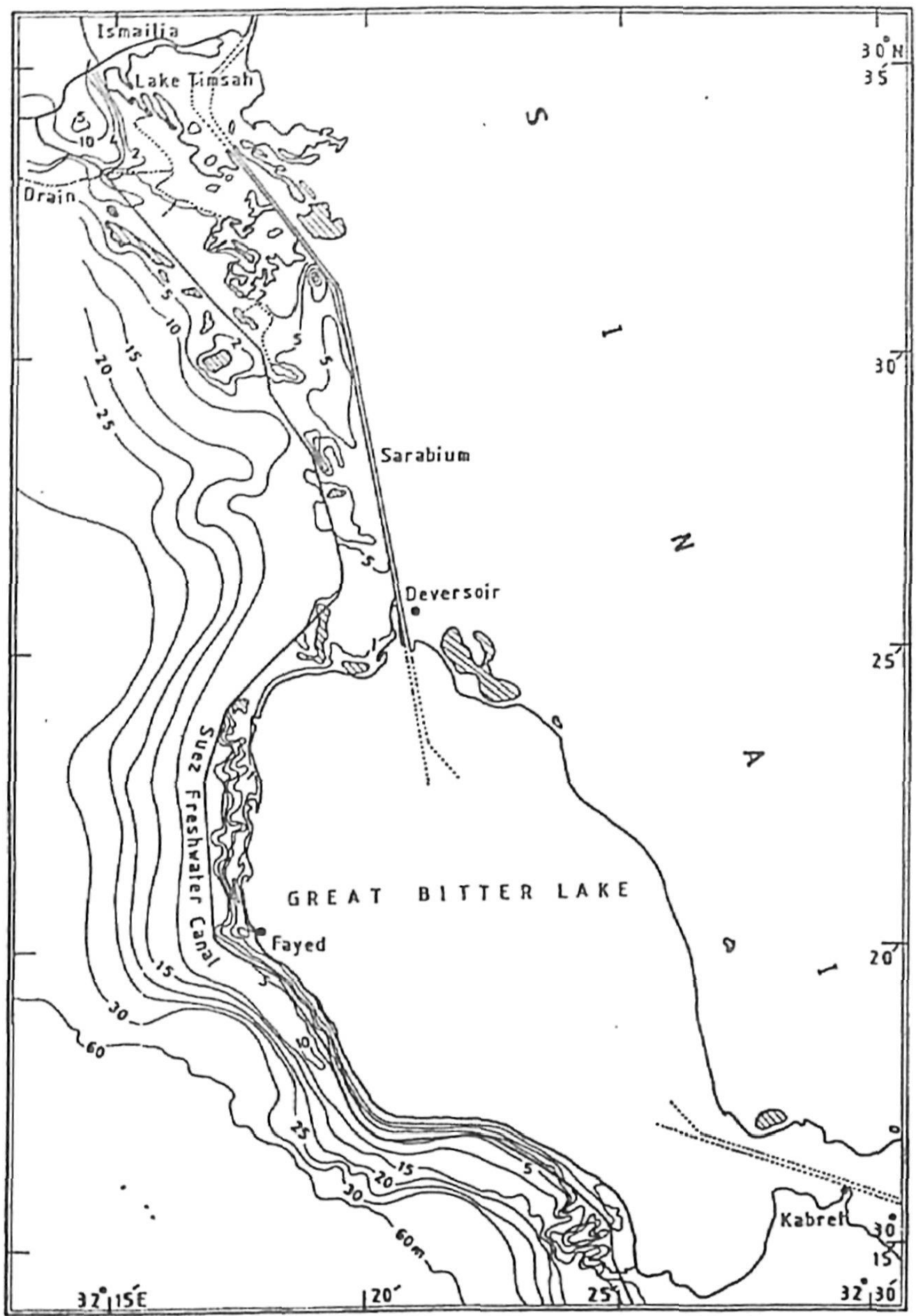

Fig.(1): Area of study. 
Amino acids as controlling factor for the mineralogy and the 161 chemistry of bivalve and gastropod shells

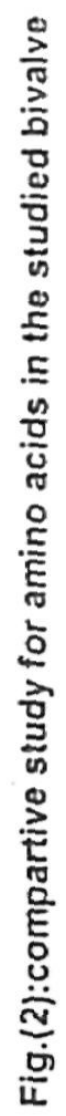

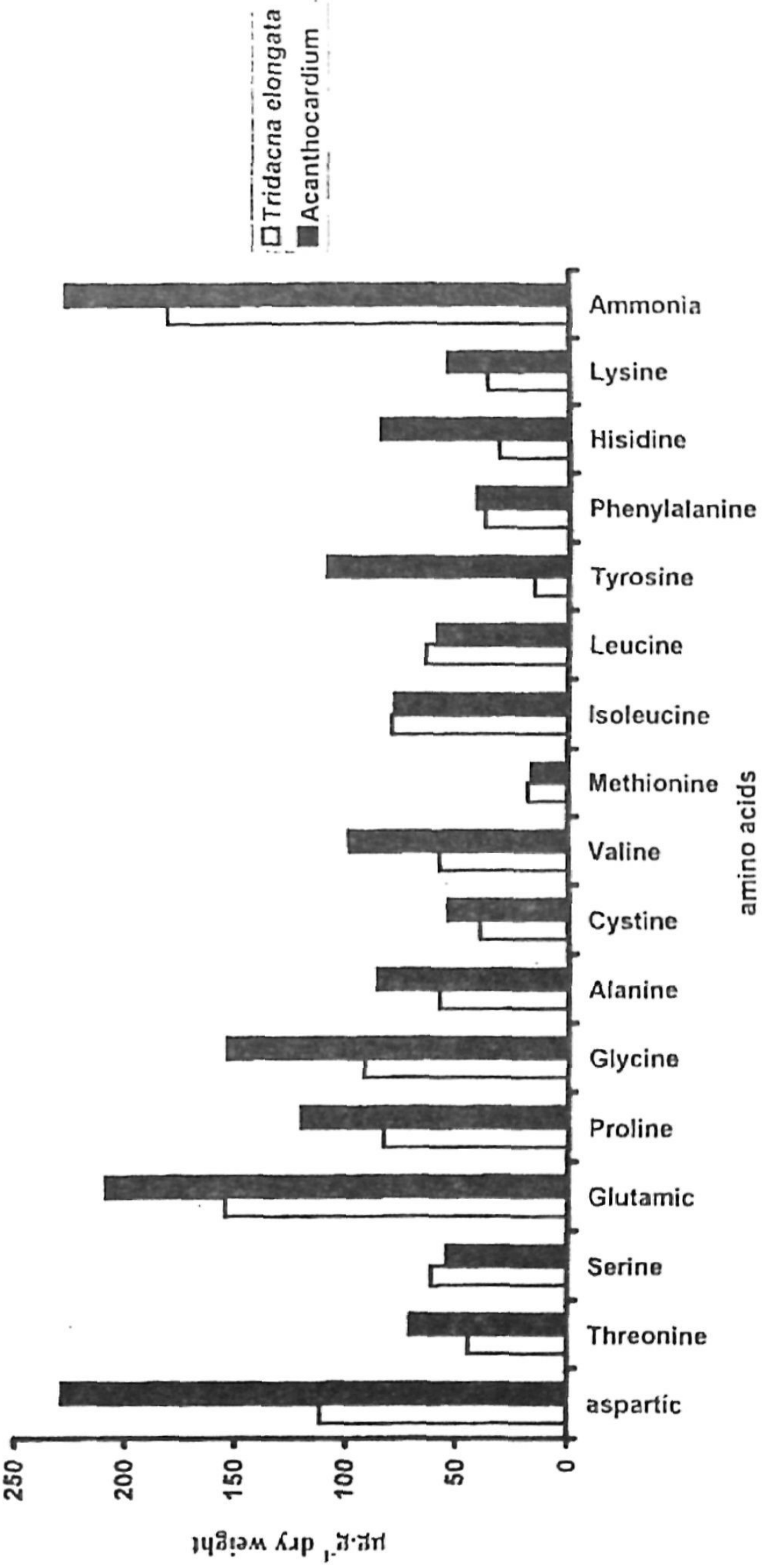




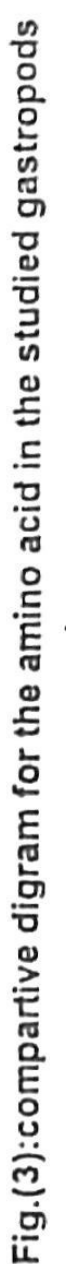

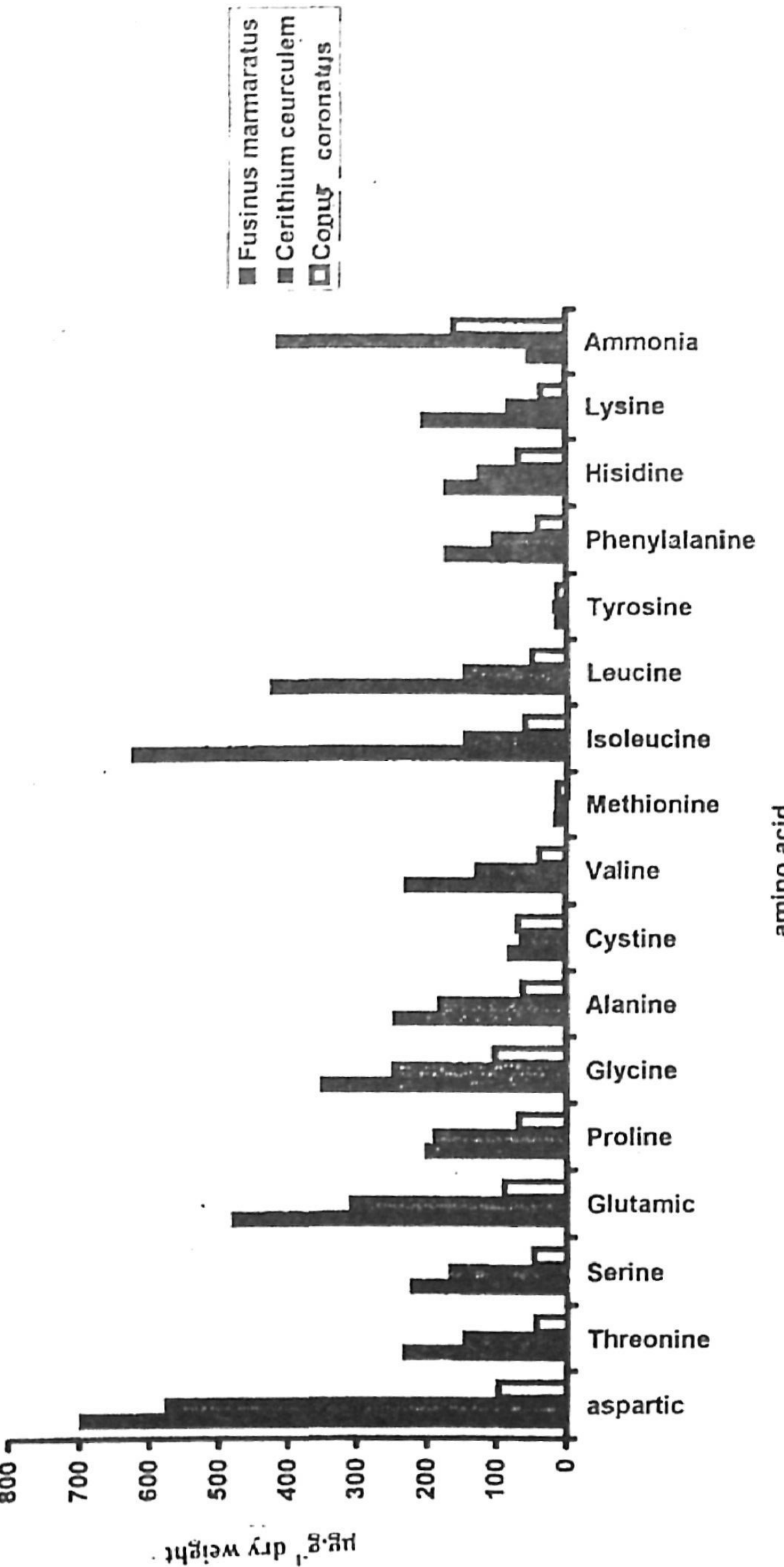


Amino acids as controlling factor for the mineralogy and the 163 chemistry of bivalve and gastropod shells

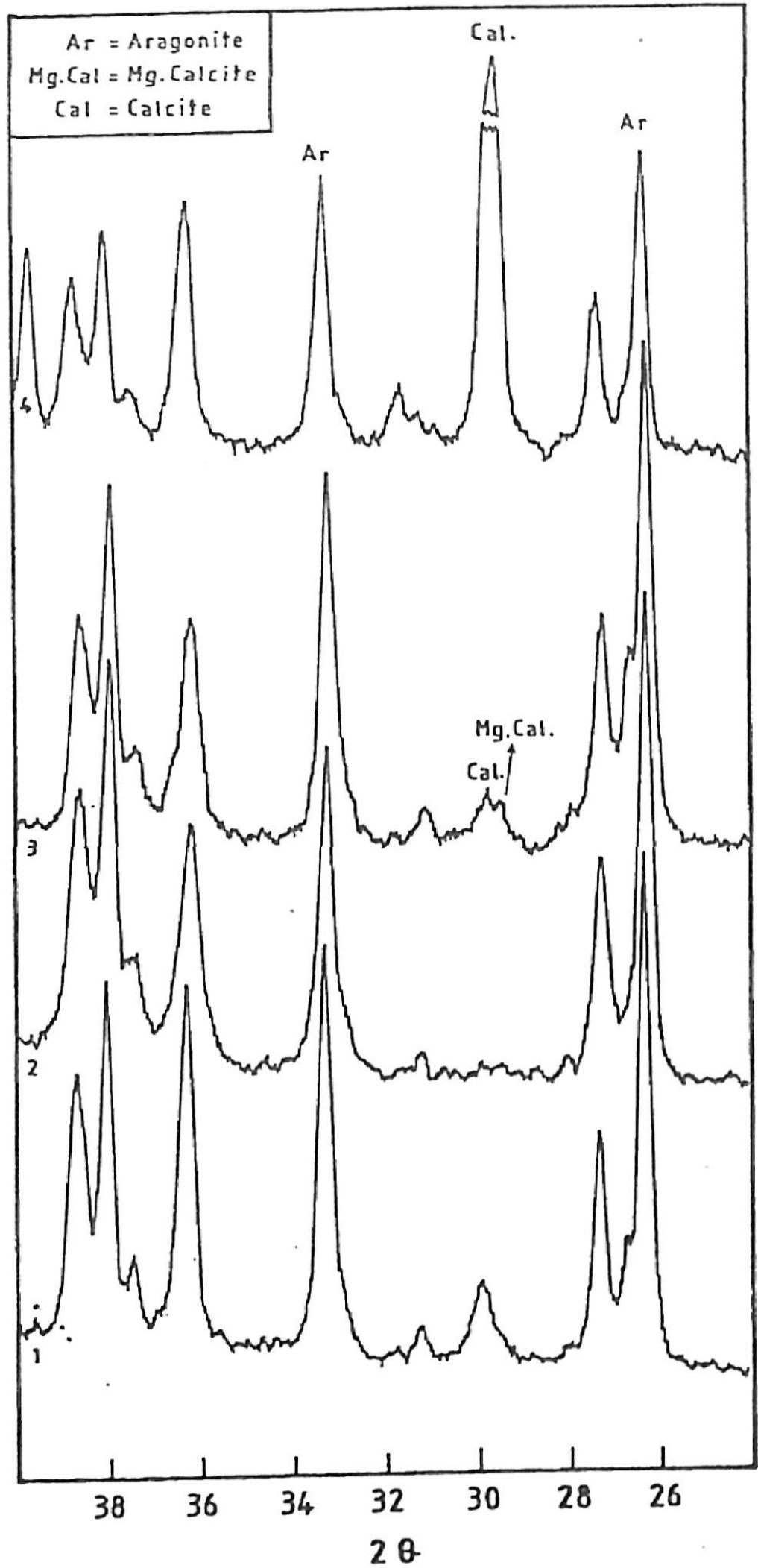

Fig. (4a): X-ray diffraction patterns for the studied shells; 1- Cerithium Caerculeum, 2- Conus coronatus-, 3- Fusimus marmoratus, 4- Acanthocardium aculeatum 


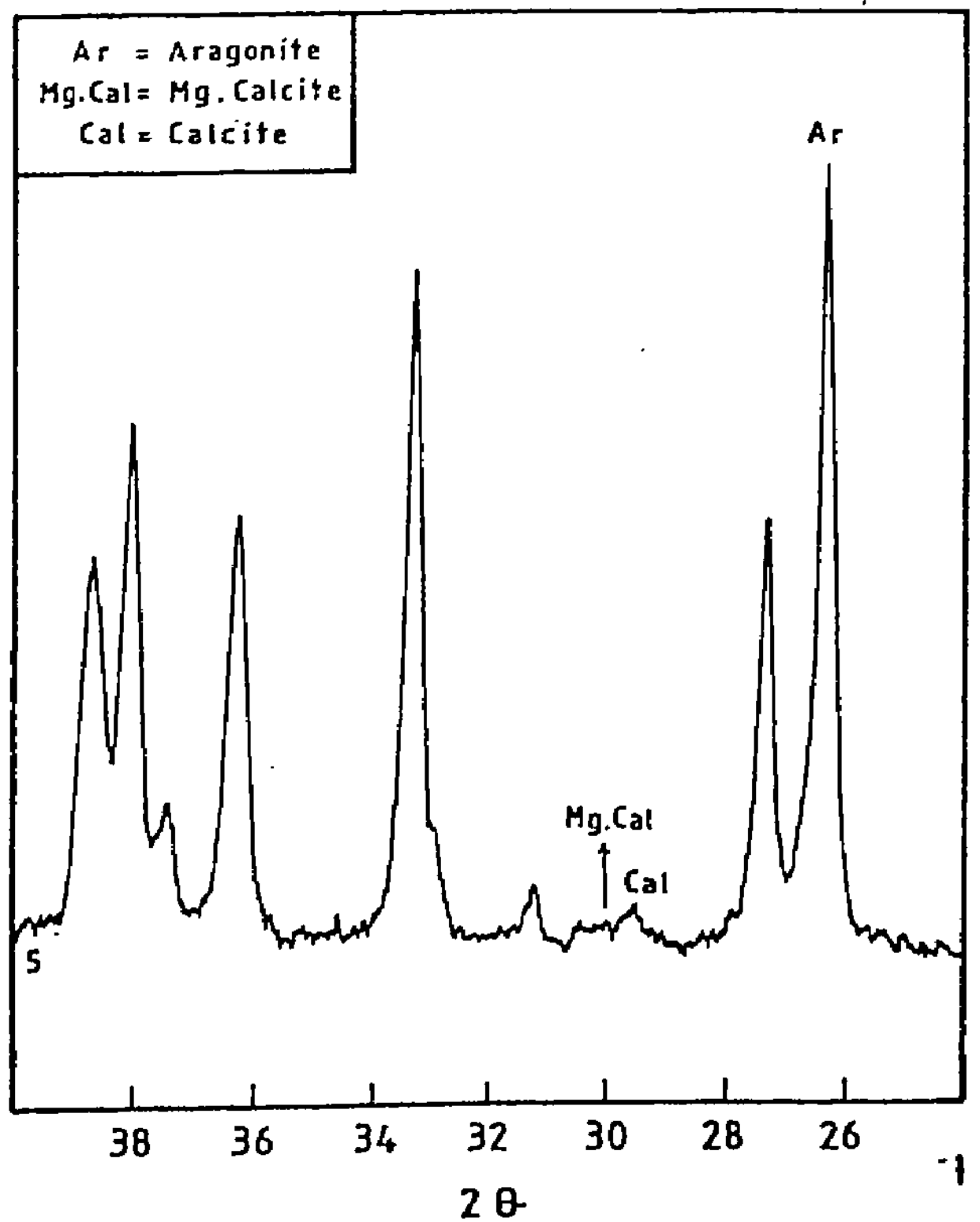

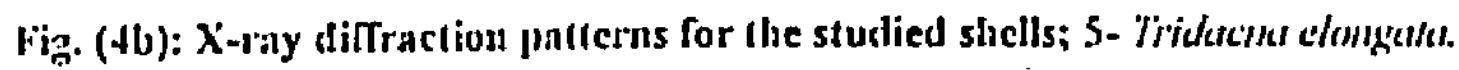


Amino acids as controlling factor for the mineralogy and the $\quad 165$ chemistry' of bivalve and gastropod shells

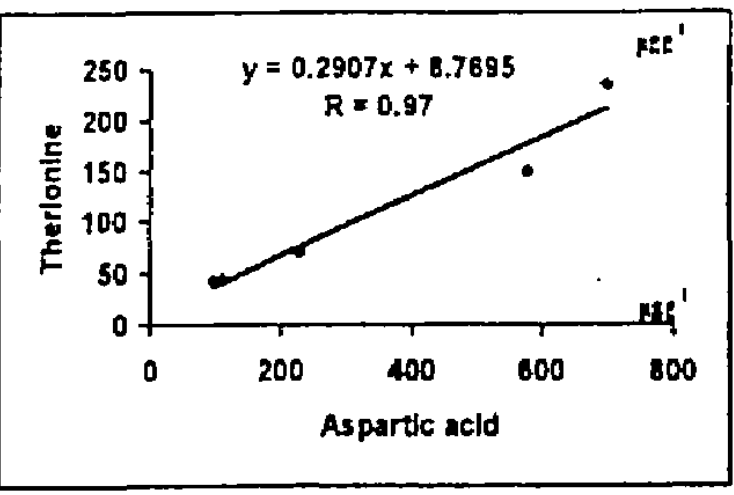

Fig. (5a): Asparlls acid-Threonine conelation In the studled spactis.

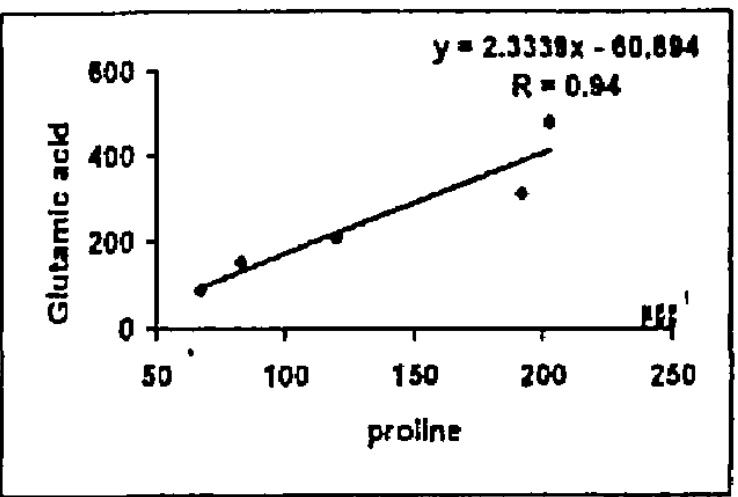

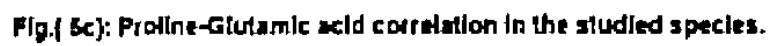

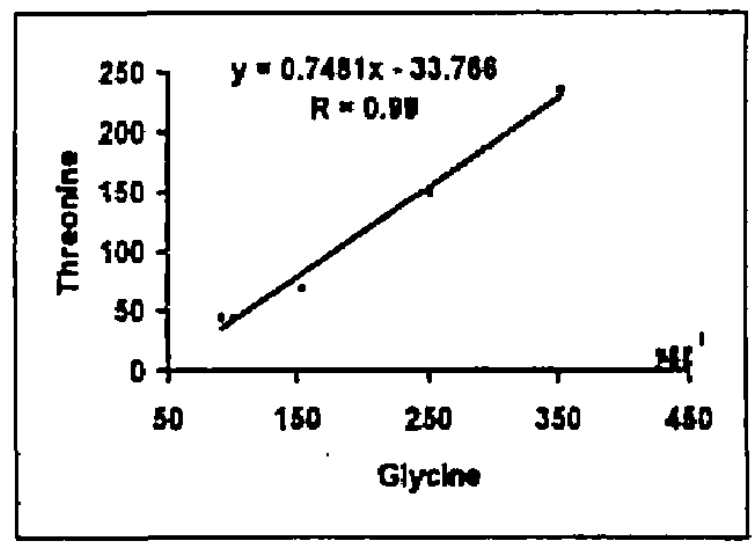

Fig. (5e): Glyclne-Theonine corretetion in the studied specles

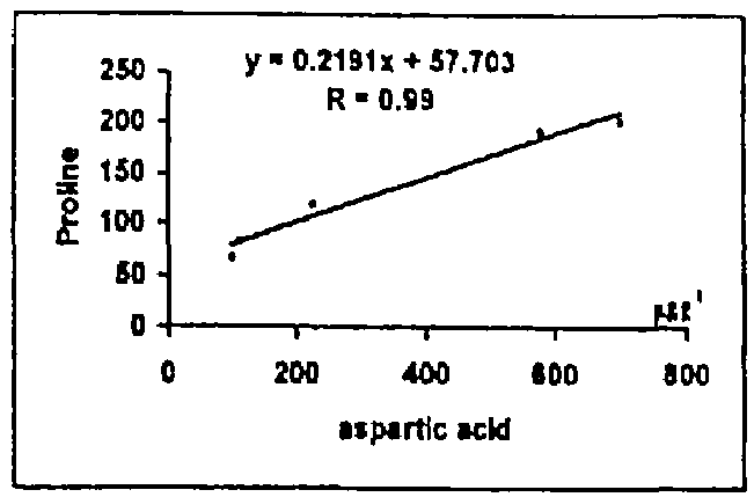

Fla.(6b): Aspartic aclaterollne cor retution in the sludied epecles.

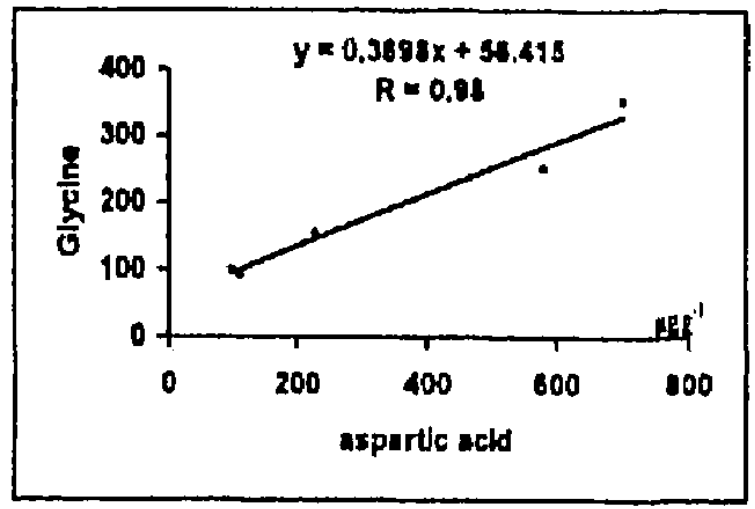

Fig. (6d j:Aaparte acid-Glycine correlatton in the atudied epacles.

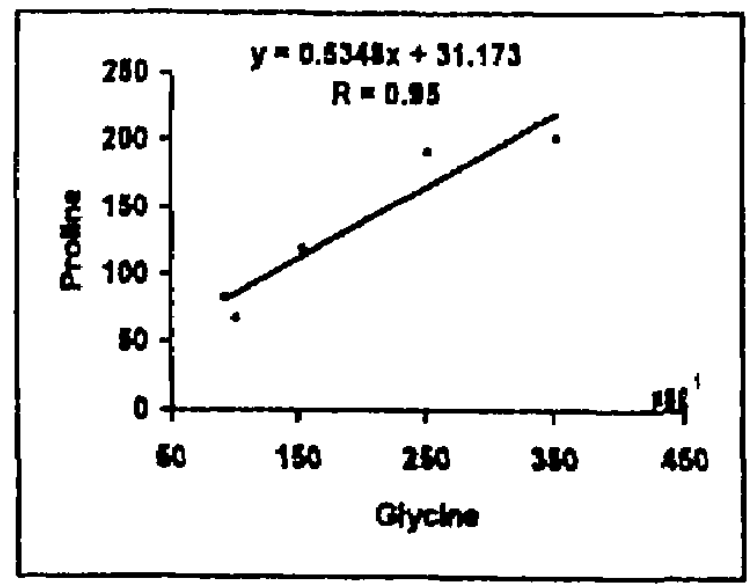

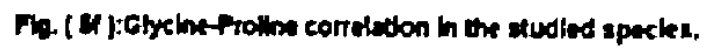




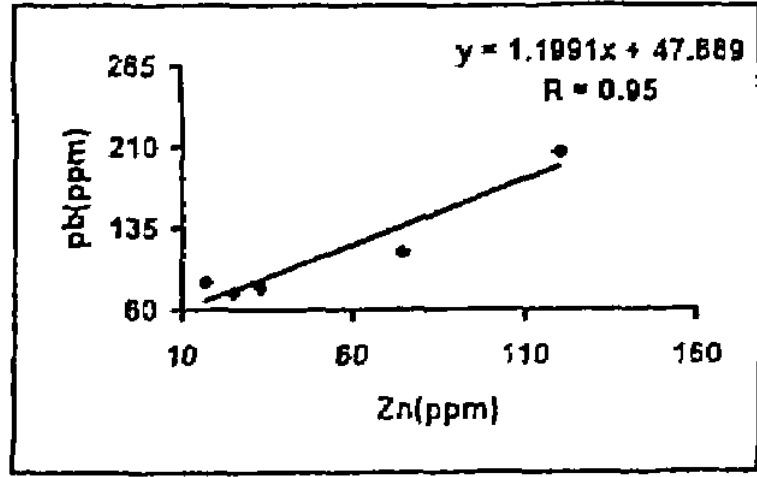

Fig. (s.): Iteod.zinc corratution in the atudled species specien

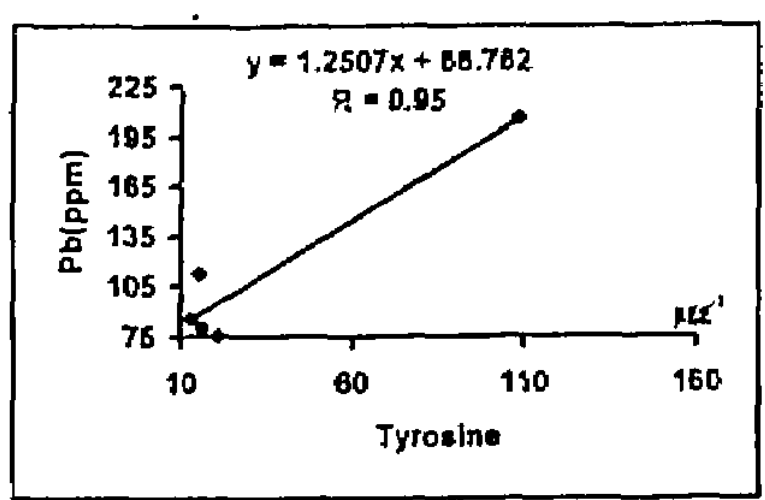

Fiv. (7\&): Pb-Tyronine carratation In the studied apecies.

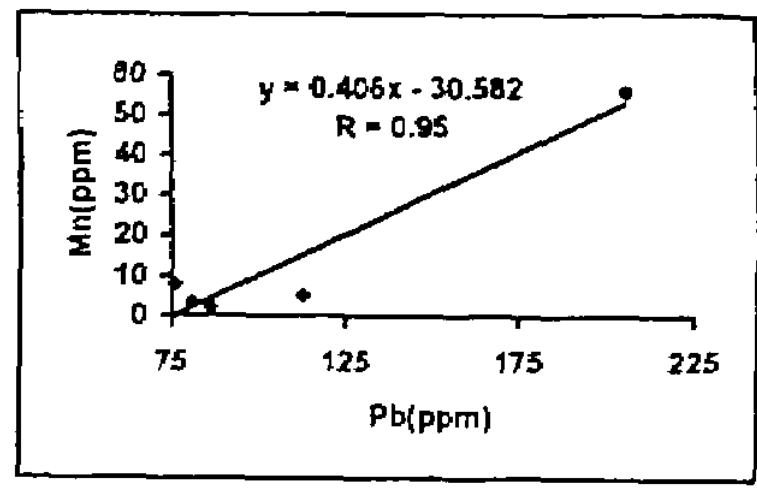

Fig.(6b): fend-mangenase corraliden in the studied stutled ip

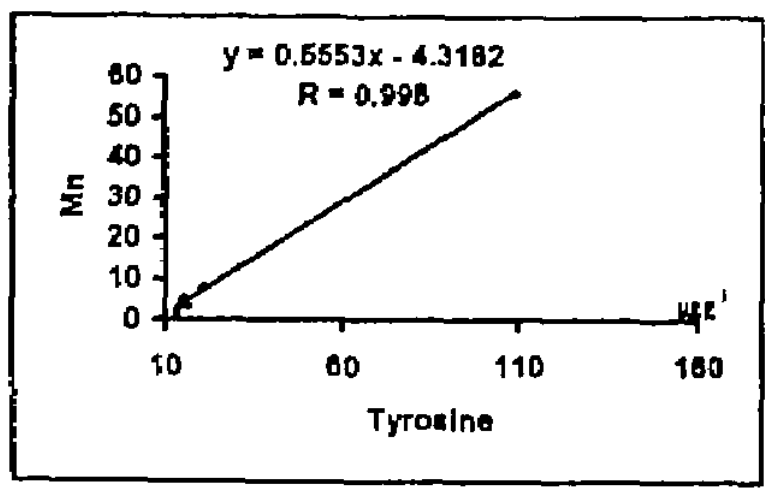

Fig. (7b ): Mn-Tyrosine cortalalion in the sludied specker. 